\title{
Results of the Local Steroid Injections in the Simple Bone Cyst
}

\section{Basit Kemik Kistinde Lokal Steroid Enjeksiyonlarının Sonuçları}

\author{
(i) Vahdet UÇAN, iD Anıl PULATKAN, iD Ahmet Can ERDEM, id Mehmet KAPICIOĞLU, id Volkan GÜRKAN
}

Bezmiâlem Vakıf University Faculty of Medicine, Department of Orthopedics and Traumatology, İstanbul, Turkey

\section{ABSTRACT}

Objective: Steroid injections represent one of the simple treatment alternatives for simple bone cysts (SBC). The aim of this study was to evaluate the results of local steroid injections in the treatment of SBC.

Methods: Seventeen patients (11 males, 6 females; mean age 12.4 years; range $=2$ to 39 years) with $\mathrm{SBC}$ were treated with injection of methylprednisolone acetate (MPA) with the use of the two-needle technique. The cysts were localized in the proximal humerus $(n=6)$, the calcaneus (one patient had bilateral lesions) $(n=2)$, proximal femur $(n=7)$ and the tibia $(n=2)$. Pathological fractures occurred in three patients before steroid injection. These three patients with pathological fractures were treated with injection of MPA after fractures healed. Each patient received a maximum of four injections at eight week intervals, each consisting of 40-160 mg of MPA. The patients were followed up with plain radiographs obtained in the first month, third month, sixth month, and at the end of a year. After the first year, patients were followed up with plain radiographs once a year. The mean follow-up duration was twenty two months (range $=3$ to 48 months). Cyst healing was assessed according to the modified Neer classification.

Results: Treatment with MPA resulted in complete recovery in ten cysts $(55 \%)$ and recovery with residual lesions in three cysts (17\%). Three cysts (17\%) did not respond to steroid treatment and two patients $(11 \%)$ developed recurrence. The results were satisfactory $(72 \%)$ in patients with complete recovery and partial recovery with residual lesions, and unsatisfactory in five patients (28\%). The patients with recurrence were treated with curettage

\section{ÖZ}

Amaç: Basit kemik kistinin (BKK) tedavi alternatiflerinden biri olan lezyon içine steroid uygulamasının etkinliğini araştırmaktır.

Yöntemler: BKK saptanan 17 hasta (11 erkek, 6 kız ; ortalama yaş 12,4 yıl; dağılım 2-39 yıl) iki iğne tekniği kullanılarak kist içine metilprednizolon asetat (MPA) enjeksiyonuyla tedavi edildi. Kist altı olguda humerus proksimaline, iki olguda kalkaneusa (olgulardan biri bilateral), yedi olguda proksimal femura ve iki olguda da tibiaya yerleşmişti. Üç hastada steroid enjeksiyonu öncesinde patolojik kırık oluşmuştu. Patolojik kırığı olan bu üç hastaya kırıkları iyileştikten sonra MPA enjeksiyonu yapıldı. Hastalara sekiz hafta arayla, herbiri 40-160 mg MPA içeren en fazla dört enjeksiyon uygulandı. Hastalar enjeksiyon sonrasında birinci, üçüncü, altıncı aylarda ve birinci yılda çekilen direkt grafiler ile takip edildi. İlk yıldan sonra hastalar yılda bir kez düz grafilerle takibe alındı. Hastaların ortalama takip süresi 22 ay (dağılım=3-48 ay) idi. Kist iyileşmesi modifiye Neer sınıflandırmasına göre değerlendirildi.

Bulgular: MPA enjeksiyonu ile 10 kistte (\%55) tamamen, üç kistte (\%17) rezidüel lezyonla iyileşme sağlandı. Üç kistte (\%17) steroide hiç yanıt alınamadı, iki hastada lezyon tekrarladı (\%11). Tamamen veya rezidüel lezyonla iyileşen hastalardaki sonuçlar tatminkar bulunurken $(\% 72)$, beş hastada (\%28) steroid tedavisi başarısız bulundu. Bu hastalar küretaj ve greftleme veya sementleme ile tedavi edildi. İşlemle ilgili hiçbir hastada komplikasyon görülmedi.

Address for Correspondence: Vahdet UÇAN, Bezmialem Vakıf University Faculty of Medicine,

Department of Orthopedics and Traumatology, İstanbul, Turkey

E-mail: vahdetucan@hotmail.com ORCID ID: orcid.org/0000-0002-6552-9197

Received: 25.02 .2019

Accepted: 15.04 .2019

Cite this article as: Uçan V, Pulatkan A, Erdem AC, Kapıcıoglu M, Gürkan V. Results of the Local Steroid Injections in the Simple Bone Cyst. Bezmialem Science 2020;8(1):68-72.

${ }^{\circledR}$ Copyright 2019 by the Bezmiâlem Vakıf University

Bezmiâlem Science published by Galenos Publishing House. 
and grafting or cementation. No procedure-related complications were encountered.

Conclusion: Our findings suggest that, the treatment with local steroid injection in SBC provides satisfactory results, thus this treatment with low morbidity can be applied to these patients before aggressive treatment.

Keywords: Simple bone cyst, intralesional injection, methylprednisolone, steroid
Sonuç: BKK tedavi alternatiflerinden olan intralezyonel steroid enjeksiyonu ile tatmin edici sonuçlar elde edilebilmektedir. Agresif tedaviler öncesinde düşük morbiditeli ve etkili olan bu tedavinin uygulanabileceği kanısındayız.

Anahtar Sözcükler: Basit kemik kisti, intralezyonel enjeksiyon, metilprednizolon, steroid

\section{Introduction}

Simple bone cysts (SBC) are the most common benign bone lesions in children and young people, making up 3\% of all bone tumors that have been biopsied $(1,2)$. These lesions are usually asymptomatic and their exact incidence and prevalence are unknown since they are detected insidental in radiology (3).

Patients with mechanical symptoms and the possibility of pathological fractures should be treated surgically to prevent cyst involution and catastrophic complications, although asymptomatic lesions that are detected as insidental in radiological examinations and do not carry the risk of pathological fractures may be followed up. Methylprednisolone acetate (MPA) injection for the treatment of SBC is a method used after being defined by Scaglietti in 1979. In traditional surgical treatment, grafting/ cementing is applied after curettage of the lesion (4).

The aim of our study was to question the results of percutaneous drainage and MPA injection treatment in SBC and determine the effectiveness of the treatment. Our hypothesis was that MPA injection was an effective alternative treatment to be tried before open surgery having more complications in the treatment of SBC.

\section{Methods}

Prior to the study, permission was taken from the Academic Lectern Council (no: 839, date; 15.01.2019). Eighteen cysts of 17 patients were included in the study who were diagnosed as having SBC and underwent MPA injection into the cyst using two-needle technique in our hospital between January 2010 and December 2015. Their data were obtained with retrospective archival scan.

The diagnosis of SBC was based on clinical experience, the radiological typical appearance of the cyst (concentric localization on the metaphysical region of long bones $(2,5)$, expansion in all directions, presence of a thinned cortex not penetrated into the physis), and the characteristic seroanginous colored fluid that came through the cyst during surgery. Patients with atypical radiologic appearance and patients who underwent biopsy due atypical material that came through the cyst during surgical drainage, were not included in the study.

Lesion volume before surgery was calculated with the Fujifilm's Picture Archiving and Communication System program according to plain radiograph and CT sections. Volume was calculated with the formula " $4 / 3^{*} \pi * \mathrm{~d} 1 / 2^{*} \mathrm{~d} 2 / 2^{*} \mathrm{~d} 3 / 2$ " (5).
The surgeries were performed under spinal, general anesthesia or a laryngeal mask, depending on the patient's condition. The procedure was performed under sterile conditions following proper surgical cleaning and age-appropriate prophylactic IV antibiotics (cephasoline 1-2 g) followed by fluoroscopy using two Jamshidi biopsy needles. After the location of the cyst was determined by fluoroscopic examination, the Cemshidi needle was carefully passed through the skin, subcutaneous tissue, muscle and periosteum and placed into the cyst (Figure 1). The presence of seroanginous fluid that came from the cyst was considered to support the diagnosis of simple bone cyst. This seroanginous fluid was sent for pathological examination in all patients. The inside of the cyst was washed with an average of $500 \mathrm{~mL}$ of saline until the flow of seroanginous fluid through the cyst ended and the flow of clear fluid began (Figure 2). After washing, the second Jamshidi needle was withdrawn and a steroid injection of 40-160 mg was given through the other needle, enough to overflow from the cyst, according to the size of the cyst, and the procedure was terminated. The patients were discharged in the day after the surgery.

The patients were given at least one and at most four times MPA injections eight to ten weeks apart. In the follow-up after injection, not seeing trabeculation which determined bone tissue formation in the cyst on plain radiographs was considered as indication of subsequent injection. Patients were followed up with plain radiographs performed in $1^{\text {st }}, 3^{\text {rd }}$ and $6^{\text {th }}$ months and in the $1^{\text {st }}$ year after injection (Figure 3 ). While the improvement in controls was evaluated radiologically, the Neer classification developed by Capanna et al. (6) was used. Stage I and II were evaluated as successful results and Stage III and IV as unsuccessful results (Table 1 ).

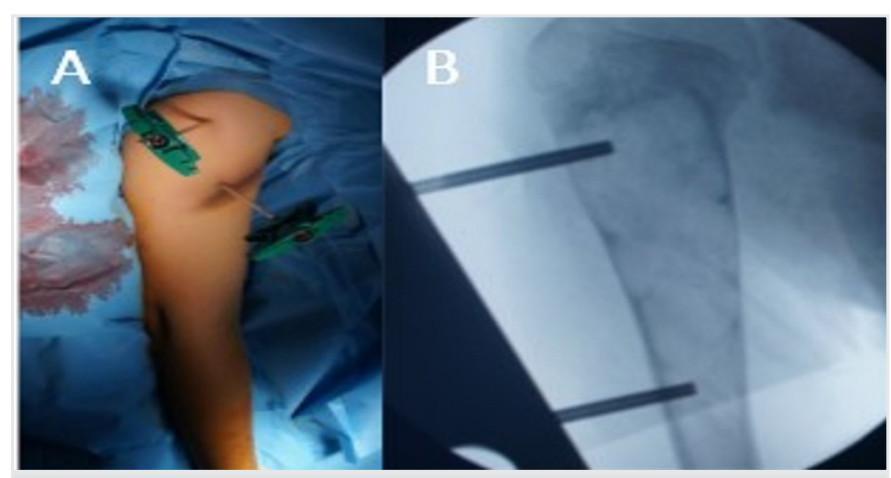

Figure 1. A) Application of two Jamshidi needles to simple bone cyst in proximal humerus and B) Fluoroscopic image 


\section{Statistical Analysis}

Statistical analysis of the data was done with IBM SPSS v20 (Statistical Package for the Social Sciences, version 20.0, IBM, Armonk, NY, USA) package program. The normal distribution of the data was evaluated by the Shapiro-Wilk test. The mean \pm standard was used to express continuous variables with normal distribution, median (minimum-maximum) was used to express continuous variables without normal distribution, and frequency (n) and percentage (\%) were used to express categorical variables. The Mann-Whitney test was used to compare two independent groups of continuous variables with normal distribution. Relations between variables without normal distribution were examined with Spearman's Rank Correlation Coefficient.
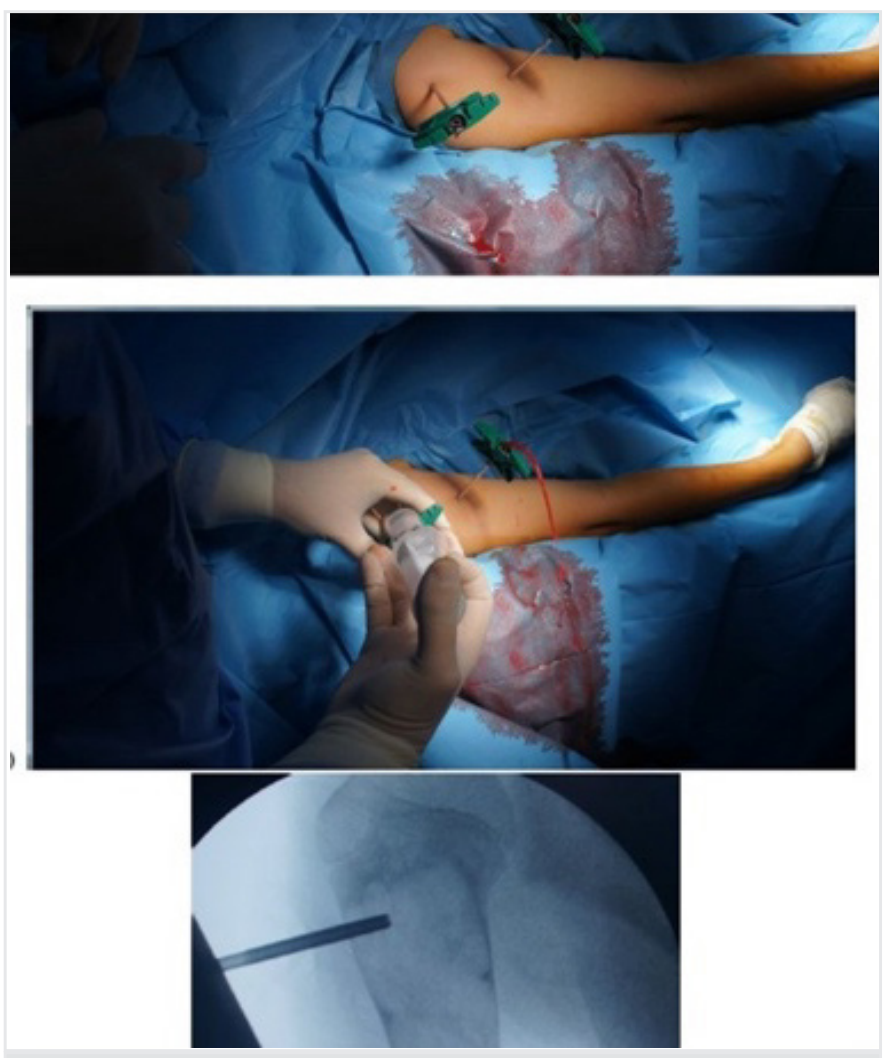

Figure 2. Discharge of seroanginous fluid in the cyst while the cyst cavity is washed with saline

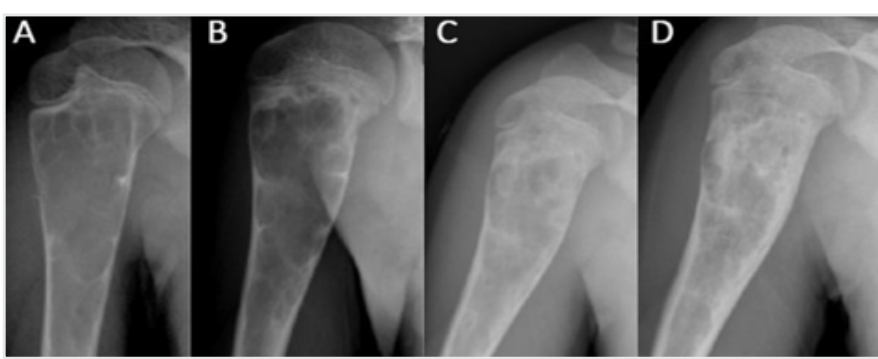

Figure 3. Type 2 improvement in follow-up plain radiographs of a patient with percutaneous steroid injection A) Preoperative plain radiograph B) Follow-up plain radiograph after injection C) Follow-up plain radiograph after injection D) Follow-up plain radiograph after injection

\section{Results}

The mean age of 11 male and 6 female patients included in the study was 12.4 years (range $=2-39$ ) and the mean follow-up period was 22.8 months (range= 3-48). In six patients, the cyst was located to the proximal humerus, in two patients to the calcaneus (bilateral in one patient), in seven patients to the proximal femur, in one patient to the proximal tibia, and in one patient to the distal tibia. Three patients had pathological fractures prior to steroid injection. These three patients were treated with steroids after their pathological fractures in the proximal humerus were healed by conservative methods. In pathological fractures with lower extremity placement, first, surgical treatment (curettage + cementing) was applied.

MPA treatment resulted in complete recovery in ten cysts (55\%) and in partial recovery with residual lesions in three cysts (17\%). Three patients (17\%) did not respond to MPA; two patients had repeated cysts $(11 \%)$. While results were satisfactory in patients with complete recovery or partial recovery with residual lesions (72\%), MPA treatment was found to be unsuccessful in five cysts (28\%) (Neer classification Table 1).

The average age of the patients with satisfactory results was 10.5 years, while the average age of the patients with unsuccessful results was 17 years. No statistically significant relation was found between age and injection result $(\mathrm{p}=0.458)$. In the five cysts where MPA treatment did not produce positive results, the average cyst volume was $24.6 \mathrm{~cm}^{3}$, while in the 13 cysts with satisfactory results, the average cyst volume was $21.9 \mathrm{~cm}^{3}$. No statistically significant relation was found between tumor volume and injection result ( $\mathrm{p}=0.961)$. The average number of injections was 2 in the patients with satisfactory results and the average number of injections was 2.4 in the five patients with failure. No statistically significant relation was found between the number of injections and the result of the injection $(p=0.681)$. None of the five patients with a successful result had a pre-treatment pathological fracture, and all three patients with a pathological fracture had a successful outcome. No statistically significant relation was found between the pathological fracture and the results $(p=0.522)$. There was no significant relation between localization and injection success when lesions were divided into two groups as lesions localized to upper and lower extremities $(\mathrm{p}=0.615)$ (Table 2).

In one of the two patients where the cyst relapsed, the lesion was in the proximal femur and the cyst volume was $9.85 \mathrm{~cm}^{3}$. In the other patient with relapse, the cyst was located in the distal

Table 1. The Modified Neer classification (6)

Stage I Consolidation with completely new bone and thickening of cortical borders

Stage II Residual defect with partial recovery (cortical thickening and consolidation)

Stage III Despite consolidation after treatment, development of osteolysis in follow-up (recurrence)

Stage IV No signs of cyst healing 
tibia and was $10.3 \mathrm{~cm}^{3}$ in size. One of three patients with no response to MPA therapy had simple bone cysts in the bilateral calcaneus. The cyst on the left side of this patient, which did not respond to steroid treatment, was $7.1 \mathrm{~cm}^{3}$ in size and was cured with grephonage after curettage. The cyst on the right side of the patient was $26.2 \mathrm{~cm}^{3}$ in size and responded well to MPA treatment. In the second patient, who never responded to steroid treatment, the cyst was settled into the calcaneus and it was $18.8 \mathrm{~cm}^{3}$ in size. This patient was also treated with curettage and grephonage. In the third patient who did not respond to steroid treatment, the cyst was located in the proximal humerus and its size was $75.6 \mathrm{~cm}^{3}$. In this patient, the cyst relapsed despite curettage and grephonage. Curettage and cementing were performed in this patient. No complications related with the procedure were seen in any patients.

\section{Discussion}

Simple bone cyst treatment continues to be challenging for orthopedists, despite numerous studies on this subject and many treatment options available. Although curettage of SBC and bone grafting is a conventional treatment for $\mathrm{SBC}$, this treatment has some disadvantages $(4,7)$. Some of these are; long surgical duration, relatively greater risk of infection, longer hospitalization, being a more morbid procedure than MPA injection. For this reason, surgeons have directed to alternative percutaneous and open treatments (8). Alternatively, methods such as intracystic injection (steroid, bone marrow, demineralized bone matrix, calcium sulfate), decompression of the cyst (multiple drilling, pin, nail) and structural support (flexible intramedullary nail) can be used. The superiority of these treatments against each other has not been demonstrated (9).

The etiology of SBC is not clear. Significant relation has been shown between SBC and bone modeling, failure in hematoma resorption, osteomyelitis, tumor degeneration, and venous obstruction (10-14). The most valid of these theories is that intralesional pressure secondary to venous obstruction is higher than bone marrow pressure $(15,16)$. Prostoglandin E2, interleukin$1 \beta$ and gelatinase in cyst fluid are known to cause resorbtion of bone. Trepination of bone has been shown to reduce pressure inside bone, regulate venous circulation and reduce the factors

Table 2. Relation between non-parametric results

\begin{tabular}{|c|c|c|c|c|c|}
\hline & & Age & Result & $\begin{array}{l}\text { Postoperative } \\
\text { follow up }\end{array}$ & $\begin{array}{l}\text { Cyst } \\
\text { volume }\end{array}$ \\
\hline Result & $\begin{array}{l}\text { rs } \\
p\end{array}$ & $\begin{array}{l}0.259 \\
0.299\end{array}$ & & & \\
\hline $\begin{array}{l}\text { Postoperative } \\
\text { follow up }\end{array}$ & $\begin{array}{l}\text { rs } \\
\text { is }\end{array}$ & $\begin{array}{l}0.232 \\
0.355\end{array}$ & $\begin{array}{l}0.355 \\
0.149\end{array}$ & & \\
\hline Cyst volume & $\begin{array}{l}\text { rs } \\
p\end{array}$ & $\begin{array}{l}0.518 \\
0.028\end{array}$ & $\begin{array}{l}0.043 \\
0.865\end{array}$ & $\begin{array}{l}0.020 \\
0.938\end{array}$ & \\
\hline $\begin{array}{l}\text { Number of } \\
\text { injections }\end{array}$ & $\begin{array}{l}\text { rs } \\
\text { p }\end{array}$ & $\begin{array}{l}0.376 \\
0.124\end{array}$ & $\begin{array}{l}0.214 \\
0.395\end{array}$ & $\begin{array}{l}0.335 \\
0.174\end{array}$ & $\begin{array}{l}0.013 \\
0.959\end{array}$ \\
\hline
\end{tabular}

that cause bone resorbtion and induce new bone formation (17). In MPA injection, cortical trepination is performed using two Jamshidi needles. Lesion decompression is achieved by opening holes. Even if the healing mechanism associated with this technique is not fully explained, it can also be thought that the anti-inflammatory mechanism play a role.

MPA injection for the treatment of SBC is a method used after being defined by Scaglietti in 1979 (18). There are different results about MPA injection in the literature. Capanna et al. showed that the success of MPA injection was $90 \%$ in cysts located in diaphysis and $94 \%$ in monolocular cysts (6). Oppenheim et al. reported a success rate of $95 \%$ (19). On the contrary, Wright et al. showed unsuccessful results in $22(58 \%)$ of 38 patients (20). In our study, ten patients $(55 \%)$ recovered completely and three patients $(17 \%)$ recovered with residual lesions. Three patients (17\%) did not respond to MPA treatment; two patients had repeated cysts $(11 \%)$. While results were satisfactory in patients with complete recovery or recovery with residual lesions (72\%), MPA treatment was found to be unsuccessful in five cysts (28\%). (Neer classification Table 1)

Scaglietti et al. (21) found $24 \%$ improvement in SBC with single injection. Campanacci et al. showed recurrence and no recovery in $32 \%$ of patients after the first injection (19). In our study, single injection was enough in only 4 (22\%) of 18 cysts. The average number of injections was 2 in the patients with satisfactory results and the average number of injections was 2.4 in the five patients with failure. No statistically significant relation was found between the number of injections and recovery.

There have been authors who have generally argued that SBC will resorbe spontaneously as age progresses $(22,23)$. Donaldson et al. showed that there was no spontaneous resorbtion in $87 \%$ of 24 paediatric patients who were followed up for an average of seven years due to SBC (24). Although the average age of the patients with satisfactory results was 10.5 years and the average age of the patients with unsuccessful results was 17 years, there was no statistically significant relation between age and satisfactory results.

Although successful results with MPA injection in the cysts in the proximal humerus were shown, the success rate of this treatment in the cysts in the calcaneus is low $(25,26)$. Glasser et al. reported that $66 \%$ of patients who underwent steroid injection required open surgery (25). Cakar et al. (27) reported $82 \%$ improvement in proximal humerus lesions with this treatment. In our study, when we divided the patients into two groups as patients having cysts in the upper and lower extremities, we found no significant relation between the cysts in upper and lower extremities in terms of the success of this treatment.

The limitations of our study are that the patient group is heterogeneous, the number of patients is limited and there is no long follow-up period. However, the possibility of recurrence of the disease is open to debate in patients who show satisfactory recovery in a short time. Further studies in large number of patients involving control groups can be planned to show longterm results. 


\section{Conclusion}

Intralesional MPA application is an effective treatment alternative that can be applied in the treatment of SBC. The antiprostaglandin effect of steroids is the basis of steroid therapy in SBC. We believe that this treatment, which is cost effective, is minimally invasive, has low morbidity, requires a short hospitalization period and is effective, can be tried before aggressive treatments. Supporting this study with studies having more homogenous patient and control groups and having longterm follow-up results will shed light on the treatment of SBC in the later period.

\section{Ethics}

Ethics Committee Approval: Prior to the study, permission was taken from the Academic Lectern Council (no: 839, date; 15.01.2019).

Informed Consent: Our study is retrospective.

Peer-review: Externally peer reviewed.

\section{Authorship Contributions}

Concept: V.U., A.P., A.C.E., M.K., V.G., Design: V.U., A.P., A.C.E., M.K., V.G., Data Collection or Processing: V.U., A.P., A.C.E., M.K., V.G., Analysis or Interpretation: V.U., A.P., A.C.E., M.K., V.G., Literature Search: V.U., A.P., A.C.E., M.K., V.G., Writing: V.U., A.P., A.C.E., M.K., V.G.

Conflict of Interest: No conflict of interest was declared by the authors.

Financial Disclosure: The authors declared that this study received no financial support.

\section{References}

1. Gennari J, Merrot T, Piclet/Legre B, Bergoin M. The choice of treatment for simple bone cysts of the upper third of the femur in children. Eur J Pediatr Surg 1996;6:95-9.

2. Wilkins R. Unicameral bone cysts. J Am Acad Orthop Surg 2000;8:217-24.

3. Kaelin AJ, MacEwen GD. Unicameral bone cysts: Natural history and risk of fracture. Int Orthop 1989;13:275-82.

4. Spence KF Jr, Bright RW, Fitzgerald SP, Sell KW. Solitary unicameral bone cyst: Treatment with freeze-dried crushed cortical-bone allograft. J Bone Joint Surg Am 1976;58:636-41.

5. Somville J, De Beuckeleer L, De Schepper A, Verstreken J, Taminiau A . Reliability of measuring volume by different methods for tumors of the musculoskeletal system. Acta Orthop Belg 2001;67:338-43.

6. Capanna R, Dal Monte A, Gitelis S, Campanacci M. The natural history of unicameral bone cyst after steroid injection. Clin Orthop Relat Res 1982;204-11.

7. Spjut HJ, Dorfman HD, Fechner RE, Ackerman LV. Solitary bone cyst. I n Tumors of Bone and Cartilage. Washington DC. Armed Forces Institute of Pathology. 1971. pp. 347-353.

8. Herring JA. General Principle of Tumor Management. Herring JA (Ed). Tachdjian's Pediatric Orthopaedics. Chapter 37, 3rd ed. Philadelphia: WB. Saunders Co, 2002: 1901-54.
9. Joeris A, Ondrus S, Planka L. ChronOs inject children with bening bone lesions : does it increase the healing rate?. Eur J Pediatr Surg 2010;20:24-8.

10. Aegerter EE, Kirkpatrick JA. Orthopedic Diseases, ed. 4. Philadelphia, W. B. Saunders. 1975, p. 438.

11. Gartland JJ, Cole FL. Modern concepts in the treatment of unicameral bone cysts of the proximal humerus. Orthop Clin North Am 1975;6:487-98.

12. Jaffe HL. Tumors and Tumorous Conditions of the Bones and Joints. Philadelphia, Lea and Febiger 1958, p. 630.

13. Cohen J. Simple bone cysts: Studies of cyst fluid in six cases with theory of pathogenesis. J Bone Joint Surg Am 1960;42-A:609-16.

14. Schajowicz F. (ed): Tumors and Tumorlike Lesions of Bone and Joints. New York. Springer Verlag. 1981. p. 417.

15. Kuboyama K, Shido T, Harada A, Yokoe S. Therapy of solitary unicameral bone cyst with percutaneous trepanation. Rinsho Seikei Geka (Japanese) 1981;16:288.

16. Ubayama IJ, Goto M, Yumawaki S. Treatment of a solitary bone cyst. Rinsho Seikei Geka (Japanese) 1977;11:1202.

17. Komiya S, Minamitani K, Sasaguri Y, Hashimoto S, Morimatsu M, Inoue A. Simple bone cyst: treatment by trepanation and studies on bone resorptive factors in cyst fluid with a theory of its pathogenesis. Clin Orthop Relat Res 1993;204-11.

18. Scaglietti O, Marchetti PG, Bartolozzi P. The effects of methylprednisolone acetate in the treatment of bone cysts. Results of three years follow-up. J Bone Joint Surg Br 1979;61-B:200-4.

19. Campanacci M, Capanna R, Picci P. Unicameral and aneurysmal bone cysts. Clin Orthop Relat Res1986;25-36.

20. Wright JG, Yandow S, Donaldson S, Marley L; Simple Bone Cyst Trial Group. A randomized clinical trial comparing intralesional bone marrow and steroid injections for simple bone cysts. J Bone Joint Surg Am 2008;90:722-30.

21. Scaglietti O, Marchetti P, Bartolozzi P. Final results obtained in the treatment of bone cysts with methylprednisolone acetate (depomedrol) and a discussion of results achieved in other bone lesions. Clin Orthop 1982;165:200-4.

22. Capanna R, Campanacci DA, Manfrini M. Unicameral and aneurysmal bone cysts. Orthop Clin North Am 1996;27:605-14.

23. Norman-Taylor FH, Hashemi-Nejad A, Gillingham BL, Stevens D, Cole WG. Risk of refracture through unicameral bone cysts of the proximal femur. J Pediatr Orthop 2002;22:249-54.

24. Donaldson S, Wright JG. Simple bone cysts: better with age? J Pediatr Orthop 2015;35:108-14.

25. Glaser DL, Dormans JP, Stanton RP. Surgical management of calcaneal unicameral bone cysts. Clin Orthop 1999;360:231-7.

26. Moreau G, Letts M. Unicameral bone cyst of the calcaneus in children. J Pediatr Orthop 1994;14:101-4.

27. Cakar M, Bülbül AM. Triple metilprednisolone injections for simple humerus cysts at one- month intervals. Eur Arch Med Res 2018;34:132-6. 